\section{A big beautiful wall against infection}

Humankind's greatest enemy has always been, and likely will always be, infection. The role of infection in idiopathic pulmonary fibrosis (IPF) is a poorly understood but the emergence of molecular techniques has renewed the focus on this area. Earlier studies of histological sections identified herpes virus DNA and haemophilus species in lung tissue. ${ }^{1}$ More recently, studies have used high sensitivity and high throughput techniques to assess bacterial species in bronchoavleoar lavage (BAL). A large number of studies have now identified divergent bacterial species in the BAL and have associated them with mechanistic processes that give biological plausibility to the role of luminal infections promoting the development of IPF. ${ }^{2-4}$

It is therefore somewhat surprising that in the study by Kitsios and colleagues that used the same techniques to assess bacterial species in the lung tissue from 40 patients with IPF but found no evidence of infection. ${ }^{5}$ Indeed levels of bacterial reads were so low that they were of the level of reagent controls, lower than negative controls and considerably lower than the samples from patients with cystic fibrosis who, as expected, had evidence of Pseudomonas and Burkholderia taxa. ${ }^{5}$

So how can the apparent paradox between an apparently sterile fibrotic lung associated with a rich diversity of bacteria in the airways of similar patients be explained? The luminal surface of the lungs and airways is easily colonised by a rich diversity of microbial species, especially when damaged, however the extent that infection may penetrate the periphery of the lung is not known. End-stage fibrotic lung characterised by dense fibrous matrix with varying amounts of cellularity and it is certainly possible that it may not be easily penetrable by microbes. However, if the alveolar space were infected one would expect it to be detectable within explanted lung tissue using the sensitive techniques employed. However, the procedures used to obtain BAL from human subjects do not permit investigators to determine the precise anatomical origin of the samples obtained. Traction change within the airways is a recognised consequence of IPF and it is therefore conceivable that the taxa observed in BAL studies are a consequence of IPF rather than its cause.

Genetic studies have identified that the airway epithelial gene MUC5B is the strongest genetic risk factor for the development of IPF, ${ }^{67}$ but high levels of MUC5b in mice protect them against infection through altering macrophage function, in contrast mice lacking functional MUC5b proteins die of overwhelming pulmonary infection. ${ }^{8}$ So is MUC5b 'walling-off' infection? Certainly the phenomenon of 'walling-off' infection is well described in abdominal infection and tuberculosis, and is thought to be a primitive response to prevent spread of infection through the bloodstream. ${ }^{9} 10$ Could it be that the bronchial epithelium acts as both a first line of host defence in the airway and early warning system to the alveoli, promoting fibrosis to aid preventing infection? Certainly the observations that the distal fibrotic lung has evidence of fewer bacterial species that normal lung despite extensive airway colonisation would support this intriguing hypothesis.

Indeed it may be a somewhat cautionary tale that the result of this 'big beautiful wall' may actually be maintaining of a sterile lung, but the cost is the destruction of the organ it was meant to protect.

\section{Gisli Jenkins}

Nottingham Respiratory Research Unit, University of Nottingham, Nottingham, UK

Correspondence to Professor Gisli Jenkins, Centre for Respiratory Research, University of Nottingham, Nottingham NG51PB, UK; gisli.jenkins@nottingham.ac.uk

Competing interests GJ reports grants from GSK, UK, MRC, Biogen, Medlmmune and Galecto; personal fees from Boehringer Ingleheim, GSK, Intermune, Medlmmune, PharmAkea, Roche, Pulmatrix, Pliant Therapeutics and NuMedii. GJ is a Trustee for the charities Action for Pulmonary Fibrosis and the British Thoracic Society.
Provenance and peer review Commissioned; internally peer reviewed.

(C) Article author(s) (or their employer(s) unless otherwise stated in the text of the article) 2018. All rights reserved. No commercial use is permitted unless otherwise expressly granted.

\section{Check for updates}

To cite Jenkins G. Thorax 2018;73:485.

Received 26 October 2017

Accepted 30 October 2017

Published Online First 14 November 2017

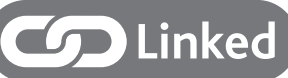

http://dx.doi.org/10.1136/thoraxjn|-2017-210537

Thorax 2018:73:485.

doi:10.1136/thoraxjnl-2017-211220

\section{REFERENCES}

1 Moore BB, Moore TA. Viruses in idiopathic pulmonary fibrosis: etiology and exacerbation. Ann Am Thorac Soc 2015;12(Suppl 2):S186-92.

2 Molyneaux PL, Willis-Owen SAG, Cox MJ, et al. Host-microbial interactions in idiopathic pulmonary fibrosis. Am J Respir Crit Care Med 2017:195:1640-50.

3 Huang Y, Ma SF, Espindola MS, et al. Microbes are associated with host innate immune response in idiopathic pulmonary fibrosis. Am J Respir Crit Care Med 2017;196:208-19.

4 Molyneaux PL, Cox MJ, Willis-Owen SA, et al. The role of bacteria in the pathogenesis and progression of idiopathic pulmonary fibrosis. Am J Respir Crit Care Med 2014;190:906-13.

5 Kitsios GD, Rojas M, Kass DJ, et al. Microbiome in lung explants of idiopathic pulmonary fibrosis: a case-control study in patients with end-stage fibrosis. Thorax 2018;73:481-4.

6 Seibold MA, Wise AL, Speer MC, et al. A common MUC5B promoter polymorphism and pulmonary fibrosis. N Eng/ J Med 2011;364:1503-12.

7 Fingerlin TE, Murphy E, Zhang W, et al. Genomewide association study identifies multiple susceptibility loci for pulmonary fibrosis. Nat Genet 2013:45:613-20

8 Roy MG, Livraghi-Butrico A, Fletcher AA, et al. Muc $5 b$ is required for airway defence. Nature 2014;505:412-6.

9 Rotstein OD. Role of fibrin deposition in the pathogenesis of intraabdominal infection. Eur J Clin Microbiol Infect Dis 1992:11:1064-8.

10 Saunders BM, Frank AA, Orme IM. Granuloma formation is required to contain bacillus growth and delay mortality in mice chronically infected with Mycobacterium tuberculosis. Immunology 1999:98:324-8. 